\title{
Pandora $\mathcal{E}$ os Reis Mendigos: ${ }^{1}$ Crise e Carisma na SOCIEDADE DA INFORMAÇÃO
}

\begin{abstract}
1 Repensar os Fundamentos da Sociedade na Sociedade da Informação. 1.1 Pandora e o Pensamento Crítico. 1.2 Obstáculos ao Pensamento Rigoroso. 1.3 Morte da Comunicação Significativa. 1.4 Fim do Pensamento. 1.5 Arqueologias. Escavar Socialmente. 1.6 As Crises. 2 Da Democracia na Sociedade da Informação e seus Inimigos. 2.1 Amigos e Inimigos. 2.2 Intolerância e Sectarismo. 2.3 Ignorância e Falta de Educação. 2.4 Fumos Comunicacionais e Degradação Mental. 3 Demagogia, Populismo e Carisma na Sociedade da Informação. 3.1 Grandezas e Misérias dos Líderes Carismáticos. 3.2 Democracia, Direito e Fanatismos. 4 Conclusão. Referências.
\end{abstract}

\section{RESUMO}

A polimórfica e ambígua Sociedade da Informação em que vivemos (também sociedade de crise permanente) encontra-se bastante à mercê da demagogia, do populismo. Teme-se o advento de líderes carismáticos (ainda que de novas formas de carisma) e o reforço de vetores religiosos e políticos fundamentalistas e extremistas pela demissão das repúblicas, que não investiram suficientemente na Educação e na Cidadania. A reflexão sobre as ameaças à Democracia, ao Estado de Direito democrático e aos Direitos Humanos em vários países parece uma tarefa irrenunciável dos Juristas que têm compromisso com a Justiça.

Palavras-chave: Crise. Sociedade da Informação. Líderes Carismáticos. Educação. Defesa do Estado de Direito Democrático.

\section{REPENSAR OS FUNDAMENTOS DA SOCIEDADE NA SOCIEDADE DA INFORMAÇÃO}

\subsection{PANDORA E O PENSAMENTO CRÍTICO}

A Sociedade da Informação (que se pode dizer um tipo de sociedade técnica de massas) (SOARES, 1969), trazendo consigo uma pletora de comodidades e mágicas invenções, pode bem ser comparada à Caixa de Pandora antes de aberta: aí se pensava residirem todos

* Professor Catedrático e Diretor do Instituto Jurídico Interdisciplinar da Faculdade de Direito da Universidade do Porto (em licença a seu pedido para trabalho internacional). Professor de Direito Internacional na graduação e de Teoria do Direito na Sociedade da informação no Programa de Mestrado em Direito da Sociedade da Informação da FMU. Bols. da Funadesp na Fadisp. Do Comité ad hoc para a Corte Constitucional Internacional. Licenciado, Mestre e Doutor pela Faculdade de Direito da Universidade de Coimbra, Doutor pela Universidade Paris II, Agregado pela Universidade do Minho, Pós-Doutor pela USP, Prémio Jabuti de Direito. E-mail: <lusofilias@gmail.com>. 
os bens, quando, na verdade, se encontravam guardados todos os males, salvo a Esperança, que permaneceu, apesar de tudo, e que é o que ainda nos vai animando.

Na verdade, há um mito alternativo que assinala estarem na realidade na caixa só bens, mas que, uma vez aberta, eles voaram para o Olimpo, abandonando os humanos (GRIMAL, 1976, p. 344).

A ambiguidade das narrativas míticas parece convir à maravilha à multiplicidade de aspetos do mundo moderno, a que se pode chamar, realmente, Sociedade da Informação.

De facto, de par com o colorido e o movimento (já existe uma ciência da velocidade, a dromologia, e ouvem-se clamores resistentes pela calma e lentidão) (HONORÉ, 2007), vieram mil e uma corveias, desde logo laborais, uma vida frenética, e de injustiças crescentes. Assim, contraditória, paradoxal, essa nova era; e, evidentemente, nem tudo é progresso apenas, ainda que simplesmente material e informacional: há, de facto, uma existência a várias velocidades, porque (para falar prosaicamente) ainda há muita gente sem canalização e luz, que fará sem televisão, telefone portátil ou computador!

Nessa sociedade, há uma grande fixação nas máquinas e na comunicação não significativa, exercendo a função fática da linguagem e pouco mais, e pouco incentivo e propensão à reflexão, que é a única garantia do pensamento verdadeiramente crítico, aquele que permite desvendar (CUNHA, 2014) e desconstruir. Embora, evidentemente, a máquina seja um produto do espírito: longa manus. O problema é deixarmo-nos dominar por elas. Não no sentido de o robot brandir o chicote, mas, naquele outro, pior ainda, de nos deixarmos voluntariamente cair na servidão à máquina e na sua dependência como um tóxico a que se ganha vício.

Nessa sociedade que aparenta tudo dar de bandeja, automaticamente (na realidade, não é nada assim: cada vez se trabalha mais e por menos), há um grande nível de preguiça reflexiva e de ritualismo de pesquisa. As pessoas pesquisam o que sempre se pesquisou e "inovam" como sempre se inovou. É muito complicado sair de alguns cânones, e a história dos vários saberes regista como penaram os poucos que ousaram trilhar outros caminhos. $\mathrm{Na}$ sociedade atual, não fugimos à regra, com a agravante de que, submergidos já pela imagem, pela velocidade, pelo lucro de um lado e pela ingência da sobrevivência pelo outro, não temos tempo nem disposição para nos aventurarmos "fora das caixinhas" [...] O conformismo é um dos grandes inimigos da cidadania.

Precisamente por todas essas debilidades do mundo atual é que é muito importante repensar os fundamentos das Sociedades em geral, até para compreender a especificidade da nossa, e pensar se não será possível (desejável pareceria ser) superar o seu círculo infernal de alienação e sonambulismo das massas. Esse repensar tem de ser feito em moldes verdadeiramente críticos. Não "críticos" como alguns pensam que deve ser todo o pensamento crítico, com todos os totens e tabus respetivos (FREUD, 2014), mas recuperando a original, matinal, pura função e intenção do ser crítico. Desde logo, nas três Críticas de Kant (a começar na primeira) (KANT, 1956) e na sua legítima posteridade. 


\subsection{OBSTÁCULOS AO PENSAMENTO RIGOROSO}

O pensamento científico, ou pelo menos rigoroso (o pensamento jurídico, segundo cremos, não é essencialmente científico, mas tópico, problemático, e, contudo, tem de ser irrepreensivelmente rigoroso), enfrenta sempre obstáculos, vícios de pensamento vários, voluntários e involuntários. Um deles é a mentira.

Há mentiras e mentiras. A pior mentira (e dita com que conviç̧ão, com que força, com que brutalidade!) é aquela que alguns dizem em alto e bom som, tonitroantemente, intimamente convencidos de que estão a descobrir e a desvendar, magnânimos, a verdade que muitos seriam incapazes de ver (na verdade, ela não existe [...] e daí não a verem), ou, pelo menos, no seu ponto de vista, só alguns eleitos seriam capazes de descobrir [...] É uma outra versão da estória do Rei que vai nu.

Imagine-se então o que será uma grande mentira (uma rede de mentiras, uma rede de crenças erróneas e nocivas) privativa de um grupo (ou em rede de vários grupos, consonantes nela), martelada, propagada socialmente [...] É um perigo, porque perante a força da convicção de alguns (e a sua capacidade de persuasão) claudica até a confiança de muitos (mais moderados, não tão cheios de si, naturalmente abertos à refutação, algo que nenhum dogmático aceita) nos seus sentidos e na sua inteligência.

Por exemplo, para ilustrar com um caso mais evidente: a força de um político enganador pode residir em negar fortemente a realidade e firmemente apresentar dela uma outra visão que, com fanatismo, apresente como a "verdadeira" realidade. Veremos isso infra com mais detença. É, pois, um perigo enorme para a sociedade indefesa. Já o seria para o simples corpo de sábios, armados de instrumentos críticos. Imagine-se para uma sociedade, como a nossa, desprovida de vacinas críticas, desprovida de anticorpos de cultura e educação.

Pior ainda se consigo esse político ou líder qualquer tiver uma legião de adeptos fanatizados, a clamar que o preto é branco e o branco é preto. Oiro sobre azul para o desconserto do Mundo é se essa mentira beneficiar diretamente (materialmente) ou confortar o ego ou aplacar a consciência dos seguidores, dos sintonizados. Essa simbiose de interesses, materiais e menos materiais, existe frequentemente nessa construção ideológica. Combinação explosiva de êxito muito seguro se lhe não opuserem energias de Civismo, Direito e Democracia.

\subsection{MORTE DA COMUNICAÇÃO SIGNIFICATIVA}

Em uma conversa em que tudo está à partida já pressuposto, sobretudo quem são os bons e os maus, o que seja (ainda que de forma confusa e até contraditória) bem e o mal, o ridículo e o grave, bastam monossílabos, risadas e impropérios. Não para as pessoas se entenderem (isso, diz o provérbio, vem da discussão, do "falar"), mas para celebrarem ritualmente a sua comunhão, que, em muitos casos, é desprezo, preconceito, maldade coletivamente assumidos. A verdadeira conversa, todavia, por natureza, seria algo de contrário a isto: uma troca 
de ideias diversas, não um ritual de ódio e uma reencenação do medíocre espírito clubístico, que se pode volver em fanatismo.

Quantos, porém, estão dispostos a ir para a luta sem as armas e bagagens de uma cumplicidade segura com os seus interlocutores? Nesses casos, mesmo quando se vê alguma discordância, seja em rodas de café, seja em salões mais o menos seletos, tem-se a impressão de que não são pessoas individuais que conversam, mas atores que encarnam diálogos velhos, representando papéis consabidos. Talvez essa tese não seja mais que levar a um estádio superior, ou às últimas consequências uma ideia que podemos já ver em Saul Bellow, e que ele precisamente exprime por uma metáfora teatral: "Suponho que todos nós temos o nosso próprio ponto, como no teatro, ou um comentador primitivo dentro de nós, o qual, desde muito cedo, nos aconselhou, dizendo-nos o que é o mundo real." (BELLOW, 1966, p. 260).

Talvez a ipseidade de alguém que é autor o leve a aceitar uma personagem individual, uma espécie de novo daimon socrático. Ora a ideia que exprimimos remete-nos para uma peça já em grande medida escrita, e um ponto que poderia ser, pelo menos para muitos, o mesmo, seguindo o mesmo texto.

Vários grandes autores chamaram a atenção para o perigo do fim da comunicação. Naturalmente, não uma sinalética utilitarista, mas da comunicação significativa, com alguma profundidade. Por exemplo, o prémio Nobel Konrad Lorenz (LORENZ, 1975, p. 137), ou o sociólogo do Direito Niklas Luhmann no seu precioso livro A Improbabilidade da Comunicação (LUHMANN, 1992).

O Direito é uma disciplina de comunicação, usa palavras e conceitos como ferramenta. A Política é arte de comunicação, usa palavras persuasivas sobretudo. Imagine-se o que é, em um caso e noutro, verificarmos que tudo ou são cartas marcadas, ou vozearia sem sentido. Pode emergir um murro na mesa que finja retificar a linguagem e dar o seu a seu dono com palavras rudes e simples. É certo que esse programa de endireitar a política pela retificação linguística e conceitual, que se deve primeiramente a Confúcio, com toda a certeza (CONFÚCIO, 1981; LEYS, 2009; CHENG, 1997), é projeto de grande vulto e seria muito proveitoso socialmente que se concretizasse. Porém, o que está em marcha é precisamente o contrário: a pretexto de clareza, está a fazer-se um empobrecimento linguístico e um encolher das ideias. Os líderes de palavras duras e aparentemente denotativas não sabem as subtilezas das coisas (ignoram ou fingem ignorar as conotações). Conhecem, afinal, poucas palavras. O seu mundo é pequeno. Como podem pretender dominar o vasto mundo cá fora das suas mentes estreitas?

\subsection{FIM DO PENSAMENTO}

A suspeita é de que, em geral, pouco se pense verdadeiramente ou não se pense mesmo nada de significativo. Não quer dizer que se não ocupe a mente: há até, pelo contrário, muito aturdimento, acredita-se que as mentes estarão tudo menos esvaziadas como em 
certas formas de meditação. Porém devem estar atoladas por superficialidades, que, aliás, logo mudam $[\ldots]$.

Tivemos uma professora que, certamente desgostosa com a pouca aplicação dos estudantes em geral à sua disciplina, acabou por desabafar, derrotada: "Afinal, há muita gente feliz, rica, saudável, que não sabe nada disto, nunca estudou e tem raiva a quem estuda [...]."

É certo que há gente realmente com existências plácidas que não precisa de pensar. Fala para relatar à noite os acontecimentos banalmente quotidianos que viveu durante a manhã e a tarde, os sentimentos elementares (reais ou copiados das novelas da televisão sempre as velhas leis da imitação) (TARDE, 1895) que calha transmitir, e os boatos e as maledicências sobre os próximos e sobre os famosos (que conhece pelos media como se foram íntimos, bem melhor que os familiares que já não visita, ou nunca visitou se for mais novo), conforme lhe vão chegando, em um arregimentado julgamento moral que é o vigente no seu círculo e nada mais que isso.

Podem acrescer, se for o caso, desgraças de família ou de amigos, por exemplo, doenças ou aventuras escolares dos filhos, netos, sobrinhos, ou interesse pelos vários tipos de modas (das de vestuário às de máquinas, avultando no caso masculino os automóveis), e fanatismo pelo seu clube desportivo, cujas peripécias (e proverbiais "roubos" pelos árbitros são um exemplo habitual) vai seguindo pela comunicação social nas suas diferentes formas, nesses casos, por vezes, com interesse genuíno.

Em alguns países e círculos, tudo é coroado com uma fé religiosa (ou afim) mais ou menos simplista e, em muitos casos, entendida de forma egoísta e "contratualista" (do ut des), não raro com negociações com a(s) divindade(s), ou seja, uma crença bastante desprovida de espiritualidade, embora, em alguns casos, que se furtam a práticas mais arcaicas, possa ter sinceridade e fé sentimentalmente muito válidas.

Evidentemente, afora maledicência e algumas poucas coisas mais, não se está aqui, evidentemente, a criticar nem os media, nem a família, nem o interesse pela saúde, a moda, o desporto ou a religião. Tirando tudo isso, fica muito pouco, certamente [...] $\mathrm{O}$ que se verifica é que, com todos esses domínios da vida, há por parte de muita gente uma relação de algum modo sonâmbula, em que se prescinde do pensamento e do verdadeiro empenhamento da pessoa. Ou então, como no caso do fanatismo religioso, político ou clubístico desportivo, pode haver uma tão avassaladora adesão totémica (ao ponto de as pessoas dizerem que são a religião, o partido ou o clube, ou que são da religião, do partido ou do clube - como, em um caso, houvesse uma identificação totémica e, no outro, uma pertença, no seguimento de verdadeira "doação de si”) que o pensamento, a individualidade e o sentido crítico se perdem.

Nessas condições, pode-se esperar controlar facilmente as massas, porque elas são muito previsíveis [...] E por isso é que a apreensão agora é maior [...] dado que os meios, na Sociedade da Informação, se sofisticaram e agilizaram. 
Mas a mesmidade é colossal. Alguns abrem a boca - tantos, na verdade - e já lhes adivinhamos o argumento. Sempre o mesmo. Sempre os mesmos temas, complexos, ódios, recalcamentos, um ou outro herói para variar (normalmente, glória efêmera daquilo que pouco interessa). Uma pasmaceira para o espírito.

Terá mesmo de ser assim? Infelizmente, o número dos que são capazes de pensar acima e independentemente da sua classe, do seu círculo social, da sua roda de amigos, dos seus interesses imediatos e mais mesquinhos, da sua carteira, e até, para alguns, das suas aspirações de ascensão social e política [...] é muito pequeno. Pensa-se pelo condicionamento social, pelas esperanças e pelo ser de bom-tom junto daqueles a quem se quer agradar, pensa-se o inevitável e o conveniente. Pensa-se, portanto, muito pouco.

É triste esse panorama, porque a Razão e a Liberdade já nos deveriam ter emancipado, mas a sociedade enclausurada (cada vez mais feudal - Agostinho da Silva já para tal chamava a atenção, nas suas "Conversas Vadias" televisivas) e a vaidade e a ganância pessoais rebaixam-nos ao nível de uma idade de opressão e obscurantismo. Em que afinal estamos, e parece que cada vez mais. Evidentemente que os vetores de alienação olham para o lado. Eles são, muitas vezes, os primeiros dos alienados. Daí a sua força de persuasão, fundada na convicção pessoal.

Quando o mero subjetivismo, as pulsões mais primárias e até o inconsciente desaguam exuberantemente no espaço público, é de temer. As manifestações laudatórias, comemorativas, encomiásticas são normalmente inofensivas (salvo quando por bem se faz mal ou se celebra o mal em si mesmo), mas as revanchistas, as vingativas, as invejosas, as odientas são perigosíssimas.

Há no catálogo da História sempre uns bodes expiatórios que sofrerão a sanha dos irados e recalcados (ECO, 2011). Os desgraçados deste mundo (humilhados, ofendidos explorados) sentem-se um pouquinho melhor quando podem contemplar a miséria dos grandes e, sobretudo, rejubilam com a sua queda dos pedestais em que faziam da sua imensa vaidade (é o princípio oculto da tragédia), assim, melhor se sentem ainda (vingados, resgatados) se podem atirar pedras, sem que um Jesus lhes lembre de que estão cheios de culpas. E depois muitos falam em Justiça, quando se trata de linchamentos públicos, trials by newspaper, e vingança difusa, vingança na pessoa de um bode expiatório.

Os demagogos cavalgam a onda da miséria moral coletiva. Mas, como não se quer ensinar História, Filosofia, Civismo e muito menos a Constituição, continuamos coletivamente ignorantes da nossa alienação.

O subjetivismo de um pensamento coletivo não pensado, de reflexos condicionados preconceituosos é eco de um conjunto de alienações coletivas. A palavra que é necessária no espaço público não é, pois, a de um subjetivismo ditado pela massa, mas a de uma individualidade crítica dirigida ao todo social, em prol da coisa pública.

Assim, público e privado se imbricam, associando-se de uma forma perversa na subjetividade da horda e de maneira benévola na objetividade racional do sujeito pensante que, na sua singularidade, pensa o universal para o Bem Comum. 


\subsection{ARQUEOLOGIAS. ESCAVAR SOCIALMENTE}

René Girard escreveu um livro cujo título vale por si: Des choses cachées depuis la fondation du monde (GIRAD, 1978). Independentemente do "argumento" da obra, de que não curaremos agora, há, de facto, muitas coisas arcanas, muitas esquecidas, muitas escondidas. E valeria a pena pelo menos desvelar algumas.

Pode para alguns parecer estranho, mas as pessoas não nascem ensinadas. Cada vez mais, nos "espantamos" ao diuturnamente o verificar. O espanto é imparável, porque há muitas coisas que espantam, evidentemente. A sociedade não é um dado adquirido, as coisas, mesmo as mais comuns e aparentemente eternas têm gênese e podem ser de forma diferente. Quando se viaja, e quanto mais se viaja para paragens distantes, mais se compreende que as pessoas são todas iguais, sim, mas também todas muito diferentes nos seus usos, costumes, crenças, rituais $[\ldots]$.

Mas, não sabemos o porquê, há certos bafejados pela sorte que sabem coisas que (aparentemente, ao menos) nunca se lhes ensinaram (dizemo-lo sem qualquer ironia e com apreço e admiração, embora no duplo sentido da palavra admiração). Talvez tenham absorvido por osmose (quiçá em famílias em que se fala à mesa e fora dela e não só vê televisão e se enfia a cabeça no celular; famílias em que ainda há e funciona a mesa familiar para refeições em conjunto), ou por processamento mental silencioso, quase inconsciente. Os especialistas dirão. É certamente desafio às novas, pujantes e fascinantes ciências cognitivas, que parece darem muito mais certezas que a velha gnoseologia filosófica.

Por outro lado, a verdade é que não temos dado especial atenção, e menos ainda em tempos mais recentes, a muitos desses conhecimentos relacionais e prudenciais que saem da intuição, certamente, ou de uma memória coletiva revisitada por alguns verdadeiramente iluminados.

É inútil pensar-se que só o decorar mecânico de umas sebentas ou manuais nos dotará de conhecimento. Os novos-ricos diplomados são por toda a parte de uma petulância monumental: neles a vaidade preenche o vazio de sabedoria, savoir faire, fair play... E tantas coisas imprescindíveis a quem queira realmente ser "testemunha da verdade", que é o significado antigo de "doutor".

Há, em contrapartida, alguns outros que chegam a formulações, distinções, e, em muitos casos, a importantíssimos "avisos à navegação", fumando um cigarro, cofiando a barba, ou até (decerto com mais esforço e menos brilhantismo) coçando a cabeça. Mas chegam lá, e a prática, a realidade dão-lhes frequentemente razão. Por vezes, infelizmente, tarde demais, porque quem devia e podia não os ouviu a tempo e horas.

Estamos, pois, a precisar de uma fase de codificação desses conhecimentos preciosos, hoje ainda avulsos, que de vez em quando nos maravilham quando saem da prudência e da clarividência de algumas "arcas da sabedoria" (que infelizmente vão desaparecendo). $\mathrm{Na}$ verdade, é já assustador o vazio, o deserto, deixado atrás de si por tantos vultos importantíssimos, sapientíssimos, que têm vindo a deixar este mundo nos últimos anos. E não se vê 
quem possa agora empunhar a chama do testemunho. As pessoas não se preparam para a sucessão, e o legado caiu no vazio. Perdeu-se, em muitos casos.

Aqueles e aquelas a quem já se vai chamando "novos bárbaros" não são analfabetos puros; são seres agitados e confusos e chegam a ser ingénuos (por vezes, muito violentos e sempre muito ávidos), mas não digeriram sequer o que lhes ensinaram (e foi normalmente pouco).

Sim, é inegável que aprenderam alguma "coisita", mas bem escassa, e não possuem a menor ideia do trato social, e da alma humana. Também não compreendem muito bem o que são coisas como poder, instituições, e menos ainda moral, ética, bons costumes enquanto discreto decoro (decorum) [...] Jamais se movem por grandeza, como sacrifício, heroicidade, ou por lhaneza ética, como lealdade, franqueza, etc [...].

Embora, em certos casos, não haja dúvida de que, de vez em quando, alguns colem ao discurso certos ademanes hipócritas deste tipo: mero efeito oratório para captar determinado público (talvez nem pensem rigorosamente em qual). E, mais que hipócritas, são pontos nem sequer bem interiorizados, nem sequer compreendidos. Porque o vero conhecimento ético é vivencial, não teórico. Cremos que tal se pode retirar até já de Johannes Hessen [...] (HESSEN, 2001).

Quem realmente sabe tem de antes de mais se aperceber dos novos tempos e das modas, e agora seria altura de colocar por escrito e em boa ordem tantas verdades, por vezes, incômodas, mas verdades.

Claro que, a fazê-lo, alguns pretensiosos iriam ditar sentenças de morrer a rir ou a chorar. Mas esperemos que os que sabem mesmo saiam da sua normal discrição e venham fazer esse serviço público benemérito. Com suavidade e firmeza (suaviter in modo, fortiter in re).

Há certamente alguns sinais exteriores de sabedoria e de nesciência: tanto dá ideia de tonto o apalhaçado como o enfatuado. O sábio, esse, tem uma pose sem pose e sem ambição, despojada, mas composta com dignidade, alheio à pompa e ao histrionismo gratuito. É, antes de mais, natural e modesto. Quem se dá ares é sempre um desastre.

\subsection{AS CRISES}

Lentamente, vamos desconfiando, e, um dia, faz-se luz, ou vemos finalmente as trevas, claramente vistas: é como se um cataclismo tivesse apagado a memória, e a Humanidade necessitasse de começar a inventar tudo de novo. Não no plano material, que nos embala com o seu progresso imparável (a tal Sociedade da Informação prescinde até de grandes equipamentos para se maravilhar com a nanotecnologia), mas no plano moral e da sabedoria social (e política). O que foi que nos tornou amnésicos? Uma bomba de neutrões do espírito deixou intacto o material, e só dissolveu a alma. Como recuperar? Há salvados por aqui e por ali. Mas como reunir o que está tão disperso?

Temos um possível diagnóstico, e isso seria meio terapêutica... O que quase nos matou na alma foi, antes de tudo o mais e principalmente: 
a) crise da educação: aí está o desmantelamento da Escola, feita depósito de pessoas e veículo de mera transmissão de saberes técnicos e dogmáticos, com ignorância do essencial, dos saberes formativos, em muitos casos, promovendo o laxismo e educando, afinal, ao contrário;

b) crise da família: culpada é a transformação da Família (por esta sociedade de ganâncias e escravizações) em uma mera célula de consumo, privando os pais de tempo, disponibilidade e sentido da responsabilidade na Educação dos filhos e na participação cívica na vida pública;

c) argentarização da política: é notória, pelo menos em alguns países, a captura de muita Política pelo poder do dinheiro, evidentemente com fenômenos, como corrupção (muitas vezes, também instrumentalizado, agora como no passado), mas também com a subordinação ideológica de muitos políticos a vagas de antipolítica e de enaltecimento puro e simples da selvática "lei do mais forte", em que avulta o economicismo e até com o esquecimento da economia política;

d) crise da intelectualidade: está à vista a demissão, a alienação e a "traição" de muitos clercs. Avultando muitos fazedores de opinião que não apenas vogam (em navegação servil de cabotagem) ao sabor dos poderes, como procuram fazer quadraturas do círculo, com piruetas mentais arriscadíssimas para legitimarem o ilegitimável.

Venham os antídotos. Devem vir depressa, porque o tecido social pode já nem aceitar os remédios daqui a pouco [...].

\section{DADEMOCRACIANA SOCIEDADEDAINFORMAÇÃOE SEUS INIMIGOS}

\subsection{AMIGOS E INIMIGOS}

Obviamente que o título desta secção é uma intertextualidade em homenagem ao conhecido livro de Karl Popper (POPPER, 1974), mas não procura segui-lo, nem sequer diretamente dialogar com ele, como se verá. A dicotomia amigo/inimigo tem todo o sentido na análise política, desde, pelo menos, e classicamente, Carl Schmitt (SCHMITT, 1992) a Julien Freund (FREUND, 1986).

A Democracia tem hoje não muitos amigos consequentes, uma multidão de falsos amigos, alguns inimigos jurados, e esbarra com alguns obstáculos. Falemos de alguns desses últimos nos pontos seguintes.

\subsection{INTOLERÂNCIA E SECTARISMO}

A posição de base de recusa de convivência com o outro traduz-se em intolerância (não se "tolera" sequer) e pode agravar-se em sectarismo. 
O sectário político pode não pertencer a uma seita, nem sequer ter ideias muito claras sobre "quem é, o que quer e para onde vai". Acha, e muito consequentemente pratica, até limites temerários (designadamente de eliminação simbólica e até física dos "inimigos", "impuros", etc.), que "quem não é por nós é contra nós”. Não confundamos sectarismo com fundamentalismo, que é conceito que nasceu em ambiente religioso, mas é uma forma especial de fanatismo. O fundamentalista é sectário, quase por definição, mas nem todo o sectário será fundamentalista.

Tem, porém, o sectarismo político uma nuance "religiosa": mesmo o correligionário pode ser excomungado politicamente se não se encaixar na ortodoxia. Porém, esta pode nem ser dogma ideológico. Por vezes, é apenas pertencer a um grupo ou bando fechado, eventualmente, uma facção dentro de um partido, o qual se quer, por exemplo, "depurar" [...] Sectarismo é assim sinônimo, politicamente, de facciosismo, uma forma específica de intransigência e, evidentemente de intolerância (já nem se fala em convivência, porque o sectário precisamente, antes de tudo se separa dos outros, e separa os demais de si: excomunga os outros e a si mesmo se excomunga com isso).

Opõem-se ao sectarismo, embora em termos latos, o irenismo e o laxismo, além do nem-nem-ismo político criticado já por Roland Barthes nas suas Mythologies (BARTHES, 1978).

O político "rolha" apto a todos os compromissos ou o "camaleão" são o contrário dos sectários: muito abrangentes e "consensuais". Demasiado.

Como ensinava já Aristóteles nas "Éticas a Nicómaco" (ARISTOTE, 1987), a virtude estará no meio. Nesse caso, certamente, entre o sectarismo e um consensualismo oportunista ou dissolvente no plano ideológico. E decerto eticamente condenável.

Pode bem compreender-se que sociedade laxistas, políticos sempre à tona da água sem convicções e coerência ideológica geram, por reação, vagas sectárias. Quando as pessoas não acreditam no establishment, viram-se para as margens, para os radicalismos.

\subsection{IGNORÂNCIA E FALTA DE EDUCAÇÃO}

A ignorância é fonte de muitos males. Não é que tenhamos uma fé cega na educação, por exemplo, tinham os clássicos iluministas (há páginas de D’Alembert, o co-diretor da Encclopédia, com Diderot, que soam a uma imensa ingenuidade nesse âmbito). Nem tudo será fatalmente bom com muita educação e ilustração. Mas, apesar de tudo, costuma ajudar... Em princípio, salvo instintos sanguinários e quando a questão é pessoal, certamente um ditador ilustrado não fará violência e afronta gratuitas ao seu Povo; um ditador bárbaro fará o mal pelo mal. Provavelmente, comprazendo-se com ele, mas pode sempre haver exceções, claro.

Foi noticiado não há muito que uma cidade da Bélgica iria canalizar cerveja. A cerveja belga é excelente, e por isso é uma ideia benemérita. Contudo, achamos que noutros países deveríamos pensar em canalizar chá. 
Sim, a falta de chá de certas pessoas, mesmo em posição de prejudicar muita gente (e não falamos de política, ou não falamos só de política: há até um punhado de políticos com chá; o que é difícil manter nos dias que correm) é tal, que deveria haver uma terceira ou quarta torneira doméstica para se poder beber chá corrente [...].

Faz falta. Claro que essa falta de chá tão visível decorre de uma atabalhoada e injusta mobilidade ascendente que tem feito com que suba (ou permaneça no topo, mas isso é menos comum: há sempre de subir, mesmo que isso seja mais rápido para alguns, como lembrou Pascal) principalmente quem se assuma como um guerrilheiro.

Classificar alguém de "guerreiro", por exemplo, em um discurso de formatura ou em uma rede social, passou a ser o máximo dos máximos do elogio na nossa sociedade impiedosa e ultracompetitiva. Acontece, porém, que, normalmente, o guerreiro não tem formação, tempo, paciência para a mínima atenção para com os outros: está obcecado pelo seu objetivo.

Mesmo o comedido e romântico Oliveira Martins apresenta o guerreiro D. Afonso Henriques, primeiro rei de Portugal, como uma personalidade bastante primária, nada simpática, preocupada apenas com a conquista, a consolidação e o alargamento do território (MARTINS, 2010, p. 64-67). Não seria, certamente, uma pessoa com quem se pudesse tomar o equivalente a um calmo e seleto chá das cinco.

Além do mais, o guerrilheiro ou o guerreiro (essencialmente hoje um social climber) é alguém sem a menor ideia das suas limitações intelectuais, de sensibilidade, de trato, de cultura e de competência. $\mathrm{O}$ ávido não se enxerga, e está obviamente apto a esquecer todas as lealdades, sem o menor escrúpulo, desprovido de consciência e flexibilidade, apenas com a fanática vontade de subir e triunfar e com até algum gosto em espezinhar os outros. No fundo, é uma vingança para profundas frustrações. Isso não se coaduna com chá, só com sangue.

\subsection{FUMOS COMUNICACIONAIS E DEGRADAÇÃO MENTAL}

A propaganda, o sectarismo, o fanatismo, o ódio e as penas e vozes a soldo de interesses, a leviandade, o ter de dizer algo sempre e todos os dias (mesmo quando se não tem mesmo nada para dizer), a vaidade da bela frase ou da ideia bombástica, a intrínseca falta de inteligência ou de capacidade de expressão, a falta de rigor e a degradação dos meios de pensar em geral são responsáveis por uma crise mental profunda.

Não se imagina o quão nocivo é dar um microfone ou uma câmara a alguém que livremente discorre sobre o que não sabe. Na nossa sociedade, há milhares, milhões que assistem a essa falsidade, a esse erro, a esse preconceito, a esse obscurantismo e vão imediatamente difundi-lo. Pior: ele pode ficar arreigado nas dobras da memória e saltar, como reflexo condicionado, na próxima conversa e, pior ainda, no momento em que seja preciso não falar apenas, mas agir. É um perigo à incultura, à petulância, à desfaçatez na comunicação social, assim como o servilismo em face de interesses, modas, etc. 
Tudo pode ser dito em democracia? Parece que sim. E ainda bem. Mas como a perfídia, o engano e o ludíbrio não pagam imposto, a democracia tornou-se pasto de quem tem espaço na comunicação social. Ninguém volta para os lugares mais importantes que são os de fazedores de opinião.

A democracia deveria ser ambiente para desabrocharem mil posições, contributos, ideias, mas todas inteligentes e construtivas. Diferentes, mas com pés e cabeça. Diferentes, mas sem segundas intenções. Diferentes, mas não a soldo de interesses.

Infelizmente, a Democracia não se defendeu nem dos escribas, nem dos clercs, nem dos clowns, nem dos tontos, nem da deseducação profunda e alheamento suicida do Povo. Como não se defendeu dos especuladores financeiros e dos agiotas.

Os demagogos e os que ganham com essa situação não querem sequer pensar em que possa haver honestidade, competência e clarividência na política. E coragem! E muito menos demofilia autêntica, baseada em democracia ética e participativa. Sociedade dita da informação, mas que mais é sociedade do espetáculo (DEBORD, 1992).

Mas não chegam os inteligentes muros das lamentações, os manifestos, os abaixo-assinados, os rasgos clássicos de flor na botoeira. Eram coisas importantes e eficazes noutros tempos. Hoje, talvez salvem a alma dos autores, mas, na verdade, nem isso [...] É necessário que quem ainda tem lucidez e liberdade encontre forças e imaginação para acordar os que andam petrificadamente adormecidos: e tanto mais adormecidos quanto mais humilhados.

A Democracia precisa, contra os obstáculos, de democratas despertos. E precisa, antes de mais, acima de tudo, como terapia de longo prazo, terapia de fundo, de muita Educação. Cultura, evidentemente, Civismo, evidentemente. Estado Social, obviamente. Mas, na base de tudo, o que tudo fundamenta e garante que tudo continuará e se aprofundará no futuro tem um nome só: Educação. Não é ensino, nem instrução, nem qualquer nome pomposo mal traduzido em jargão tecnocrático. Educação.

A grande libertadora e integradora no sentido positivo é a Educação a sério. Para todos, mesmo. Por exemplo, lembramo-nos bem como a investigadora de origem chinesa Anne Cheng elogiou no College de France a escola republicana que lhe permitiu estudar e singrar.

Em regra, os privilegiados não se apercebem da injustiça e da tortura que é alguém ter qualidades, vocação, querer estudar e não poder, por falta de dinheiro. Hoje, até docentes têm dificuldade em estudar, tantas as suas funções adventícias. Tanto a burocracia os distrai e os impede de fazer a sua verdadeira função: pesquisar e ensinar, mesmo. Mas pior é querer estudar e ter de trabalhar só para sobreviver. É triste, revoltante.

Urge reivindicar o direito a estudar. E não deixar que vagas e bolsas vão para quem não quer estudar, não tem vocação ou capacidade. Meros diletantes (quantos deles simplesmente com vontade de viajar e aparecer em selfies nas redes sociais) não mais podem usufruir o que deveria ser para quem merece.

Há mal entendidos sobre a função da Escola. Não se vai à Universidade aprender um saco de técnicas para ser rico, poderoso e famoso. Visa-se aí ao enriquecimento espiritual 
e cultural no convívio com o espírito universitário. Pela sabedoria, prudência, ilustração, moderação e conhecimento, estar-se-á habilitado ao trato humano, não ao serviço da técnica sem alma ou do nu poder.

\section{DEMAGOGIA,POPULISMO,CARISMANASOCIEDADEDAINFORMAÇÃO}

\subsection{GRANDEZAS E MISÉRIAS DOS LÍDERES CARISMÁTICOS}

Sempre convivem passado e futuro, resíduos e derivações (PARETO, 1968). Em uma sociedade da informação muito sofisticada, que alguns acreditam "pós-moderna", há resíduos de formas de dominação muito antigas, sobretudo do tipo carismático (embora também, por vezes, mantenham-se ainda uma ou outra liderança patriarcal) (WEBER, 1978), que constituem bolsas antidemocráticas e vetores de reação à própria Modernidade.

Já Teilhard de Chardin alertava para aqueles nossos contemporâneos que nem sequer são modernos (TEILHARD DE CHARDIN, 1955). É um fenômeno perigoso que está aí de novo, em tempos de populismo e demagogia e falta de credibilidade em alternativas classicamente democráticas, em muitos países.

Seria importante fazer uma psicologia do candidato a líder populista e mesmo do já líder. Julgamos que uma característica infalível dessas pessoas é uma enorme vaidade e ambição e outra certo autismo ao real mesmo real, falando e agindo como se o mundo fosse o que há na cabeça. Ao mesmo tempo, há um mimetismo por parte desses líderes a que alguns já abertamente chamam fascistas, que lhes faz assumirem a cor local, como camaleões, servindo para se servirem: "Os fascistas não são estúpidos e são mestres na arte da mentira. [...] o fascismo, devido à sua angustiante falta de ideias e ausência de valores universais, assumirá sempre a forma e as cores do seu tempo e da sua cultura." (RIEMEN, 2012, p. 72).

Há pessoas que se julgam encarnar determinados grupos ou pomposamente "valores" (embora normalmente sejam antivalores ou ilusões em vez deles), que creem ser verdadeiras instituições ou, então, julgam-se porta-vozes inspirados, iluminados, ungidos de certas mensagens que dizem ir salvar o mundo. E pensam ter muita importância e poder por, do alto do seu banquinho (começa com um banquinho, mas pode ir muito longe), proferirem de dedo em riste admoestações, ridicularizações, interditos, anátemas, exclusões, excomunhões e afins. Para eles, o Mundo resume-se a esse pequeno círculo em volta dos respetivos umbigos.

E esquecem que qualquer um que lhes não preste atenção, encolha os ombros e se ria das suas opiniões e desejos está livre, completamente livre, da sua inexistente jurisdição. Isso em uma primeira fase, enquanto não ganham dimensão de massas. Aí as coisas começam a mudar de figura, e a ameaça passa a ser muito real.

Se fossem órgãos do Estado, se tivessem real poder, seriam muito de temer, porque a sua autoestima é de ego gigantesco, e a sua noção do real completamente distorcida pelo solipsismo egoísta e egocêntrico. Mas não. São normalmente senhores da sua roda de bar, 
do seu clube de bairro, da sua empresa sem dimensão (microempresa é dizer demais), a sua seita fanática. Isso, no início, como dissemos. Mas seria bom que nunca passassem do início, e então a magnânima democracia até os poderia tolerar, como uma espécie de reserva ecológica ou museológica da antidemocracia. Embora haja dúvidas, porque permitir o caldo de cultura dos vírus letais é sempre perigoso.

Não cremos que sejam nunca felizes esses ditadores de pacotilha, esses profetas do óbvio ou do impossível de comprovar, esses treinadores de bancada, esses advogados de lareira. Os súbditos de que necessitam serão cada vez menos em sociedades sadias, civilizadas. Só colonizam mentes atrofiadas e almas sem asas. Mas de tanto martelarem o seu ódio, é impossível que a máscara se lhes não cole ao rosto. Devem sofrer muito por viverem em um mundo tão contrário ao que pregam. Tão escandalosamente livre, democrático, respeitador do Direito. Ainda que ele o seja não suficientemente para as pessoas normais e, em especial, para os democratas e os juristas que se comprometem com a Justiça.

Os mais infelizes de todos devem ser os fundamentalistas, que, no fundo, acusam Deus por não ter criado um mundo imutável e perfeito e se substituem a ele para criar o seu céu pessoal na terra. Como sugeriu brilhantemente Gabriel Périssé:

Todo fanático religioso termina recriminando a Deus. Impaciente com a bondade divina, chateado com a misericórdia de um Deus não-fanático, o fanático gostaria de criar um novo Deus, à sua imagem e semelhança. Um Deus mais engajado, mais atento, mais preocupado com os desmandos do mundo. [...] A obra fanática sonha recriar o mundo. Não entende como Deus pode ter sido tão descuidado, deixando tantas heresias proliferarem como moscas. Os fanáticos, reunidos semanalmente, olham para as estatísticas e planejam dar umas férias para Deus tão incompetente. [...]. A partir de agora, queira Deus ou não, vamos assumir tudo por aqui. Sem alardes, mas com profissionalismo. [...] Cabe à obra fanática, a última coisa coerente e bela neste mundo sem rumo, recolocar a humanidade nos trilhos. Se Deus quiser aproveitar a oportunidade, ótimo. Se preferir continuar fingindo que está tudo bem... problema d'Ele! (PÉRISSÉ, 2007, online).

De uma pureza à outrance, mas, afinal, fabricantes de infernos (para aproveitar um título, e só ele, de Agostinho Caramelo.) (CARAMELO, 1972) «Qui le dirait! La vertu même abesoin de limites.», diria um Montesquieu [...]. (MONTESQUIEU, 1979, p. 4).

\subsection{DEMOCRACIA, DIREITO E FANATISMOS}

Acaba por haver guetos de verdadeiro despotismo (nada iluminado) mesmo em sociedades macrodemocráticas, e não raro os seguidores de fanáticos, lunáticos, extremistas abdicam de alguns dos seus direitos ao menos, ao seguirem esses líderes. Desde logo, o freguês habitual que se cala (e chega até a assentir), perante o discurso absurdo, mas empolado e enfático na tasquinha da esquina, começa por prescindir da sua liberdade de expressão. E hipotecou a sua liberdade de consciência, mas, desde essa aparentemente pequenina condescendência, que, na verdade, já é grande cedência, pode passar-se a uma total entrega de corpo e alma. Não é par délicatesse j'ai perdu ma vie. É por cobardia mesmo. 
O Direito, sem deixar obviamente de ser tolerante com as mais variadas formas de interação social dentro da legalidade, tem de arquitetar esta no sentido de garantir os direitos das pessoas, mesmo, no limite, protegendo-as da sua ingenuidade. E do mesmo modo que não pode premiar o burlão pela sua eventual argúcia em ludibriar, não deve ficar de braços cruzados ante fenômenos de fanatismo institucionalizado, sobretudo quando assumam vestes militarizadas, paramilitares ou ecoem ventos de sangrentas ditaduras passadas.

É óbvio que não vai imiscuir-se em bagatelas, nunca. Não é um escuteiro empenhado na sua boa ação diária que acabe por obrigar velhinhas a atravessar a rua. Sempre haverá alguma injustiça e ludíbrio fora do olhar da Lei. É inevitável. Um sistema jurídico que pretendesse erradicar a menor injustiça seria, pelo poderoso aparelho que deveria mobilizar um Estado totalitário. Summum jus, summa injuria, diziam os Romanos.

Mas quando começa a ser exagerado o descaso ou a afronta à Lei e aos Direitos, a ordem jurídica não pode esquivar-se em uma venda que, na verdade, nunca terá tido (como explicamos no nosso Desvendar o Direito) (CUNHA, 2014).

Toda a fanatização é potencialmente subversiva de um Estado de Direito democrático, venha de onde vier. Por um lado, há o perigo de crescimento da fanatização por líderes que dizem coisas simples e iradas, parecendo ter descoberto a pólvora e serem os únicos a falar verdade (enquanto os demais, políticos, sacerdotes, comunicação social, enfim, tutti quanti, teriam um discurso redondo, abstrato, sensaborão, ritualizado e, sobretudo, hipócrita). Mas pode haver uma forma mais subtil de fanatização: a religiosa ou ideológica, mais independente da figura do líder carismático. Então, são as ideias e as crenças que arrastam as massas. É um nível talvez menos primitivo de seguidismo, mas ainda assim o é, evidentemente. Se a ideologia, a religião soprarem no fole da intolerância, da violência, da segregação, etc.

Os moderados de todos os quadrantes (e o leque é bem variado, incluindo os mais diversos matizes) podem ter entre si querelas fortíssimas, divergências agudas, mas comungam todos de uma mesma devoção precisamente pelo pluralismo político e social que permite que discordem. No dia em que um grupo, seja de que coloração for, quiser impor a sua lei a todos, pintar a Cidade da sua única cor, tout est perdu, para usar uma expressão de Montesquieu n'O Espírito das Leis. E os meios de comunicação na Sociedade da informação são tais que o incêndio pode alastrar com uma velocidade imensa e com enorme incapacidade de ponderação (e reação defensiva ao menos) dos atingidos.

As democracias têm o péssimo hábito de serem muito laxistas no desenvolvimento e na defesa da ética republicana e das próprias instituições democráticas. Acreditam, com uma ingenuidade suicida, que o bem da democracia está à vista de todos e que essa luz por si só dissipa as trevas, como na Flauta Mágica de Mozart. Mas não, nas democracias, o que vem ao de cima são os seus erros, os seus podres, a corrupção que lhe não é própria por essência, mas ocorre como epifenômeno. $\bigcirc$ que as pessoas não educadas veem é, assim, o que não é específico da democracia e tomam a nuvem negra e corrupta pela casta e etérea Juno. 
Os jovens que não conheceram as ditaduras, sem educação, desde logo, sem educação histórica, sociológica, filosófica e afim vivem um cinzento presente e chegam mesmo a ser seduzidos por saudosistas. Se tivessem conhecido o látego e a canga da tirania, não suspirariam com ar blasé pela sua vinda. Incapazes de um pensamento crítico, colocam um sério problema porque deles depende o futuro. Eque futuro? Os melhores de entre eles são grande esperança (os melhores são, na verdade, excelentes) serão capazes de reverter o processo de decadência, e de guinada antidemocrática?

A verdade é uma só: Não, não seríamos mais felizes se fôssemos governados no macrossocial pelos pequenos reizinhos que pontificam em círculos menores, com vaidade resplandecente ainda que com coroas de papelão. Nem seria bom voltarmos ao passado de má memória: para quem a tem.

Por isso é que, salvo o guru (patriarcal e não carismático) do bar da esquina, que é obedecido e reverenciado talvez pela sua idade e pela memória de alguma façanha lateral na sua juventude quiçá (real ou mitificada), que se recorde no bairro, os líderes bonapartistas com dotes carismáticos não ficam o dia todo consumindo cerveja e aplausos de uma meia dúzia de indefetíveis.

São reis mendigos, que partem à conquista do Mundo e, desde logo, ao arregimentamento de adeptos que possam vir a ser a sua guarda pretoriana e tropa de choque. Seduzindo, mostrando-se falsamente servidores, apontando escandalizados (quantas vezes hipocritamente) os erros dos outros, afivelando pureza e eficiência, para depois implantarem a sua tirania. Onde prosperarão todos os males da democracia, apenas escondidos, e ainda mais alguns, sendo severamente punido quem ouse levantar o véu da podridão.

Ouvem-se vozes de trovão, pessoas com solução para tudo e simplismo de arrepiar. Vai havendo já a identificação de bodes expiatórios. Já vimos esse filme. A História já viu esse filme.

Foi assim que as coisas começaram em uma cervejaria de Munique. E depois ecoou por anos na rádio uma voz irada, enquanto se ouvia a música de fundo de botas cardadas, os ares se poluíam do fumo dos fornos crematórios e, por vezes, toldava o sol a sombra letal dos bombardeamentos [...].

\section{CONCLUSÃO}

A Sociedade da Informação, em que nos encontramos, necessita ser bem dissecada, ponderando as possibilidades extraordinárias de propagação da demagogia e de movimentação e inflamação das massas, dos meios que, pelo contrário, deveriam ser postos ao serviço da Educação, da Cultura, da harmonia social e da Paz.

Um primeiro principium sapientiae será de ultrapassar o preconceito cronocêntrico otimista, segundo o qual devemos ficar muito satisfeitos por as crianças de hoje saberem mexer com sofisticadas máquinas informáticas, como se tivessem nascido ensinadas. Sim, 
e, ao mesmo tempo, há adultos que deveriam ter cabeça sobre os ombros sendo vítimas da alienação. Agora, mais informatizada, mais em tempo real, mais colorida, nomeadamente presos a máquinas de controlo das suas vidas e escravização laboral, que não param sequer durante o sono $[\ldots]$.

Seria necessário avaliar criticamente o bem e o mal para a democracia, o Estado de Direito e os Direitos Humanos de todo esse Brave new world que já está aí, quer dizer, aqui.

Há muita mistificação sobre a democracia, e ela parece pouco se importar com o seu futuro, como se soubesse de antemão que "a ditadura segue dentro de momentos". Mas há quem não se conforme com essa sina.

Para se ter democracia são precisos democratas, que trabalhem por ela e lutem por ela. Não se faz uma democracia pintando de fresco adeptos de ditaduras, nem esperando que nasçam democratas de geração espontânea. É preciso democratas com currículo antiditatorial e mais: vontade de sempre lutar pela democracia. A democracia é quotidiano trabalho de Sísifo. Não se pretende, é evidente, que, nas democracias, haja uma casta de gerontes condecorados por façanhas antigas e governando sobre novos que não tiveram tempo de mostrar o que valem. O que, sobretudo, choca é a reciclagem e a reconversão dos que precisamente mudam facilmente de barricada [...].

Por outro lado, não pode haver uma sociedade democrática se não for o poder político (limpo, republicano, íntegro) a dizer a última palavra, quer dizer, se não houver, realmente, soberania popular, exercida por representantes do povo e não comprometidos com poderes-outros, nomeadamente financeiros e econômicos, mas que podem também ser religiosos, etc. Não se pode nomeadamente confiar que instituições voltadas ao lucro improdutivo possam colaborar com um sistema de Finanças a favor do Povo. Uma das primeiras medidas a tomar seria ensinar bem a todos como funcionam as Finanças reais e as instituições do dinheiro. Enquanto esse tipo de saberes for esotérico, nunca o povo terá um controlo real sobre essa determinante essencial da sua vida (RUSSELL, 1957). Basta um banco meter-se em apuros, pela especulação ou pelo desfalque interno, e gerações de cidadãos honestos e laboriosos, que nada têm a ver com esse banco, poderão ver as suas vidas comprometidas e as dos seus. E tudo parece passar-se com tranquilidade.

Mas o sistema político precisa regenerar-se. Fala-se em muitos países em reforma do sistema político, mas normalmente são apenas mudanças cosméticas, certamente, em alguns casos, sinceras, mas superficiais. Muitos países acabam por ter uma opinião pública ou setores dela, que não pensam soluções adequadas ao país em causa, à sua idiossincrasia, apenas cuidam que importar a solução adotada pelos vizinhos (e de que eles se queixam, não raro) irá ser panaceia. É preciso ir mais fundo, mais longe. Sem obviamente por em causa os sacrossantos princípios do Estado de direito democrático, do Estado constitucional de hoje (HAEBERLE, 2003). Trata-se de adquiridos irreversíveis, se não quisermos regressar a qualquer forma de barbárie.

Uma Sociedade da Informação começa pela comunicação social clássica e depois 
sofistica-se nas novas tecnologias de informação, mas, em todos esses meios, é preciso bom senso, sentido da liberdade, Direito equilibrado e atualizado, não pela "engenharia legal", mas por verdadeira sabedoria jurídica para a democracia.

Não adianta muito (pode até ser muito complicado) ter comunicação social e partidos políticos só aparentemente livres: se forem ecos de interesses outros que a ideologia que coloquem nos seus documentos fundadores (estatutos editoriais e declarações de princípios). É preciso comunicação social independente, muito independente, e partidos identificados com programas e ideologias, e não com simples burocracias e lideranças.

Fomos repisando que a Educação era a grande base. Paideia telion ton nomon, já diziam os Gregos. A educação é mesmo superior às leis. E é-o, sempre. De muito pouco, vale gastar milhões com a educação se os professores (por seu turno mal pagos e aviltados na sua dignidade por mil e uma formas de rebaixamento e humilhação, a que todos os dias assistimos, além da intimidação, por vezes) forem de algum modo incentivados a não ensinar grande coisa (desde logo, a não serem verdadeiros educadores, só tecnólogos e burocratas), a não avaliar com rigor e os programas a não formar cidadãos de pleno direito. Enchendo normalmente a cabeça de crianças e adolescentes com catadupas de coisas (mais ou menos, inócuas e raramente formativas) a decorar e esquecendo as matérias que, sendo formativas e culturais, ficariam para toda a vida.

As ideologias difusas que pregam um igualitarismo radical, mas vago e, em muitos casos, profundamente injusto (note-se que a Igualdade é um valor altíssimo, mas é preciso saber do que se trata) são contrárias às elites, que confundem propositadamente com oligarquias. Ora nada é mais diverso de uma oligarquia que uma elite.

A oligarquia é um clique normalmente ociosa e pérfida até que vive à custa do sangue, do suor e das lágrimas dos outros. Uma elite, pelo contrário, é uma vanguarda social, esforçada, virtuosa e responsável, que dedica a sua vida ao serviço.

Dir-se-á que era já esse o ideal de cavalaria, que não funcionou na Idade Média. Não sabemos se não funcionou na exata medida em que se exerceu. Não sabemos se houve poucos cavaleiros andantes na defesa dos órfãos e das viúvas. Sabemos, claro, que as condições gerais do feudalismo não ajudavam o ideal da cavalaria. Sabemos que não sabemos, sobretudo. E, independentemente de objeções e comparações, não conhecemos outro modo de o Povo se defender sem que haja um setor mais esclarecido, com disponibilidade e determinação para ser seu "representante". Pode trair, claro, algum desses seus elementos poderão trair. Isso é inevitável. Mas qualquer movimentação desarticulada e meramente impelida pela raiva não faz sequer revoluções, faz Jacqueries.

Não se terá uma democracia (nem Direito) a sério, pois, sem uma elite (não uma oligarquia) pensante, de pessoas respeitadas e não vexadas permanentemente e com direitos cada vez mais confiscados.

O problema é que, pela Educação (escolar e familiar) e pelos Media, haveria que previamente preparar essa elite para que o fosse: imbuída de uma mística a que sinteticamente 
se poderia chamar ética republicana (CUNHA, 2010). É preciso que essas pessoas desinteressadas e altruístas sejam formadas nessa mística e que haja condições para que triunfem as boas ideias, que, afinal, não são nada de mirabolante, porque tudo mais ou menos foi dito. Resta só concretizar, sem traições e seduções por sereias desvirtuadoras.

Em cada país, em geral, a respetiva Constituição é um excelente programa mínimo cujo cumprimento, por si só, faria já uma enorme revolução de Direito, Democracia e grandes avanços sociais, culturais, ecológicos, civilizacionais, além disso, haveria uma boa convivência. Bastaria, pois, concretizar as Constituições e, também, honrar os compromissos internacionais firmados pelos Estados por tratado (CHEMILLIER-GENDREAU, 2013).

A proposta da criação de uma Corte Constitucional Internacional vai nesse sentido (BEN ACHOUR, 2017); e é sintomático que ela não propugne a feitura de uma qualquer Constituição mundial, nem seja favorável à quimera do Estado mundial. Em grande medida, lhe bastariam as constituições nacionais, os grandes tratados e documentos afins, designadamente as Declarações de Direitos.

Os mais altos valores não residem nem nos que tudo possuem, nem nos que nada têm. Os quais, normalmente, não têm noção da sua situação, e até se eventualmente riem da Liberdade (ROUSSEAU, 1762). Uma classe média responsável e minimamente culta seria excelente para afinar o exemplo social. A ascensão social de muitos trabalhadores à classe média nos últimos anos em vários países faz com que não se trate do mero burguês instalado (SOMBART, 1966), mas de alguém com maior dinâmica, o "burguês empreendedor", se quisermos (HOURDIN; GANNE, 1967) (na verdade, ainda nem se tratará de burguesia). Mas é preciso quem viva esse exemplo, o pense e o aperfeiçoe criticamente [...].

A Ética está como abóbada de toda a intervenção social, pois não se faz política de bem com pessoas de mal. A seleção do pessoal político e, em especial, dos que têm cargos de responsabilidade não pode ser deixada ao descaso da seleção natural, em que normalmente não ascende e triunfa o melhor, mas o mais aguerrido, ou o mais truculento: o tal "guerreiro" [...]. Não é fácil, porém é preciso encontrar pessoas irrepreensíveis na sua conduta pública, que corram o risco de dar a cara.

Se tivermos consciência do que está realmente em jogo e se confrontarmos os desafios das nossas democracias crepusculares com o grande programa que, pela positiva, possuem diante de si, veremos que a Sociedade da Informação não pode ser considerada como o plácido fim da História (FUKUYAMA, 1992), nem como a morte do Homem (SIMAK, 1955), vivendo simplesmente aventuras coloridas em um fantástico e ímpar mundo virtual.

Em síntese, como explica Flusser: "O que está acontecendo em volta de nós e dentro de nós mesmos é fantástico e todas as utopias antecedentes, positivas ou negativas, estão perdendo as cores perante o que está emergindo." (FLUSSER, 2008, p. 13). 


\title{
PANDORA \& THE BEGGAR KINGS: CRISIS AND CHARISMA IN INFORMATION SOCIETY
}

\begin{abstract}
The polymorphic and ambiguous Information Society in which we live (also a permanent crisis society) finds itself quite at the mercy of demagogy and populism. We fear the advent of charismatic leaders (albeit in new forms of charisma) and the reinforcement of fundamentalist and extremist religious and political vectors due to the dismissal of the republics, which have not sufficiently invested in Education and Citizenship. Reflections on the threats to Democracy, the Democratic Rule of Law and Human Rights in various countries seem an indispensable task for jurists who are committed to justice.
\end{abstract}

Keywords: Crisis. Information Society. Charismatic Leaders. Education. Defence of the Democratic Rule of Law.

\section{PANDORA Y LOS REYES MENDIGOS: CRISIS Y CARISMA EN LA SOCIEDAD DE LA INFORMACIÓN}

\section{RESUMEN}

La polimórfica y ambigua Sociedad de la Información en que vivimos (también sociedad de crisis permanente) se encuentra bastante a merced de la demagogia, del populismo. Se teme el surgimiento de líderes carismáticos (aunque con nuevas formas de carisma) y del refuerzo de las repúblicas, que no invistieron suficientemente en la Educación y de Ciudadanía. La reflexión sobre las amenazas a la Democracia, al Estado Democrático de Derecho y a los Derechos Humanos en varios países parece una tarea irrenunciable de los Juristas que tienen compromiso con la Justicia.

Palabras-clave: Crisis. Sociedad de la Información. Líderes Carismáticos. Educación. Defesa del Estado Democrático de Derecho.

1 Este artigo não nos parece ter nenhuma similitude com o título de Jean Lartéguy, Les rois mendiants. Mera intertextualidade e homenagem nossa, apenas no significante. Em si mesmo evidentemente original, ele retoma, lima, aprofunda e repensa (além de aprofundar e relacionar), em certos aspetos, alguns temas e textos aparecidos esparsamente em imprensa cultural portuguesa, nomeadamente na nossa colaboração em "As Artes entre as Letras." 


\section{REFERÊNCIAS}

ARISTOTE. Éthique à nicomaque. Paris: Vrin, 1987.

BARTHES, Roland. Mythologies. Tradução de José Augusto Seabra. Lisboa: Edições 70, 1978.

BELLOW, Saul. Entrevista a Gordon Lloyd Harper. Seleção, Tradução, Prefácio e Notas de Carlos Vaz Marques. Entrevistas da Paris Review, Lisboa - Tinta-da-China MMX, 1966. BEN ACHOUR, Yadh; CUNHA, Paulo Ferreira da. Pour une cour constitutionnelle Internationale. Oeiras: A Causa das Regras, 2017.

CARAMELO, Agostinho. Fabricantes de infernos. 2. ed. Lisboa: [s.n.], 1972.

CONFÚCIO. The Analectos. Tradução do chinês de Anne Cheng. Paris: Seuil, 1981.

CHEMILLIER-GENDREAU, Monique. Obliger les états à tenir parole. 2013. Disponível em: <https://www.monde-diplomatique.fr/2013/09/CHEMILLIER_GENDREAU/49597>. Acesso em: 1 maio 2017.

CHENG, Anne. Histoire de la pensée chinoise. Paris: Seuil, 1997.

CUNHA, Paulo Ferreira da. Desvendar o direito. Lisboa: Quid Juris, 2014. . Para uma ética republicana. Lisboa: Coisas de Ler, 2010.

DEBORD, Guy. La société du spectacle. Paris: Gallimard, 1992.

ECO, Umberto. Construir o inimigo e outros escritos ocasionais. Lisboa: Gradiva, 2011. . O cemitério de praga. Lisboa: Gradiva, 2011.

FLUSSER, Vilém. O universo das imagens técnicas: elogio da superficialidade. Revisão Técnica de Gustavo Bernardo. São Paulo: Annablume, 2008.

FREUD, Sigmund. Totem e tabu. Tradução de Renato Tzwick. Porto Alegre: L\&PM, 2014. FREUND, Julien. L'essence du politique. Paris: Sirey, 1986.

FUKUYAMA, Francis. O fim da história e o último homem. Tradução de Maria Goes. Gradiva: Lisboa, 1992.

GIRARD, René. Des choses cachées depuis la fondation du monde. Paris: Grasset, 1978. GRIMAL, Pierre. Pandora. In: DICTIONNAIRE de la Mythologie Grecque et Romaine. Prefácio de Charles Picard. 5. ed. Paris: Presses Universitaires de France, 1976.

HAEBERLE, Peter. El estado constitucional. Estudo Introdutório de Diego Valadés. Tradução e índices de Héctor Fix-Fierro. México: Universidad Nacional Autónoma de México, 2003. HESSEN, Johannes. Filosofia dos valores. Tradução portuguesa de Luís Cabral de Moncada. Coimbra: Almedina, 2001. 
HONORÉ, Carl. Éloge de la lenteur. Paris: Marabout, 2007.

HOURDIN, Georges; GANNE, Gilbert. Os valores burgueses. Tradução de Alfredo Barroso. Lisboa: Livros do Brasil, 1967.

KANT, Immanuel. Kritik der reinen Vernunft. 2. ed. Hamburgo: Felix Meiner, 1956.

LEYS, Simon. De -551 à Aujourd'hui. Confucius les voies de la sagesse. Dossier coordenado por Minh Tran Huy. Le Magazine Littéraire, n. 491, p. 66, nov. 2009.

LORENZ, Konrad. Entrevista in mais além com. Europa-América: Mem Martins, 1975.

LUHMANN, Niklas. A improbabilidade da comunicação. Tradução João Pissarra. Lisboa: Vega, 1992.

MARTINS, Joaquim Pedro de Oliveira. História de Portugal. [S.1.]: The Project Gutenberg E book, 2010. Tomo I.

MONTESQUIEU. De 1 'Esprit des lois. Paris: Garnier-Flammarion, 1979.

PARETO, Vilfredo. Traité de sociologie générale. Genève/Paris: Droz, 1968.

PÉRISSÉ, Gabriel. O Fanatismo Religioso é um Ateísmo. Correio da Cidadania, São Paulo, set. 2007. Disponível em: <http://www.correiocidadania.com.br/colunistas/gabriel-perisse/809-04-09-2007-o-fanatismo-religioso-e-um-ateismo>.

POPPER, Sir Karl R. A sociedade aberta e seus inimigos. Belo Horizonte: Editora Itatiaia; São Paulo: Editora da Universidade de S. Paulo, 1974.

RIEMEN, Rob. O eterno retorno do fascismo. Tradução Maria Carvalho. Lisboa: Bizâncio, 2012.

ROUSSEAU, Jean-Jacques. Du contrat social. Amesterdão: Marc Michel, 1762.

RUSSELL, Bertrand. O elogio do lazer. Tradução Luiz Ribeiro de Sena. São Paulo: Companhia Editora Nacional, 1957.

SCHMITT, Carl. La Notion de Politique. Paris: Flammarion, 1992.

SIMAK, Clifford D. A cidade no tempo. Lisboa: Europa-América, 1955.

SOARES, Rogério Ehrhardt. Direito público e sociedade técnica. Coimbra: Atlântida, 1969.

SOMBART, Werner. Le Bourgeois. Paris: Payot, 1966.

TARDE, Gabriel De. As Leis da Imitação. Porto: Rés, 1895.

TEILHARD DE CHARDIN, Pierre. Le phénomène humain. Paris: Seuil, 1955.

WEBER, Max. Wirtschaft und gesellschaft: grundgriss des verstehenden soziologie. [S.1.]: University of California Press, 1978. 2 v.

Submetido: 3 maio. 2017

Aprovado: 6 jun. 2017 